\title{
Covalent attachment of a transition metal coordination complex to functionalized oligo(phenylene-ethynylene) self assembled monolayers
}

\author{
Abhishek Dube $^{\dagger}$, Andrew R. Chadeayne ${ }^{\ddagger}$, Manish Sharma ${ }^{\dagger}$, \\ Peter T. Wolczanski ${ }^{\ddagger}$, and James R. Engstrom ${ }^{\dagger} * *$ \\ ${ }^{\dagger}$ School of Chemical and Biomolecular Engineering \\ and \\ ‡Department of Chemistry and Chemical Biology \\ Cornell University \\ Ithaca, New York 14853 \\ *To whom correspondence should be addressed,jre7@cornell.edu
} Supporting Information (10 pages) 


\section{Experimental procedures}

\section{A. Synthesis of self-assembled monolayers}

Materials. The following chemicals were purchased from Sigma-Aldrich Corp. (St. Louis, MO) and used as received: tetrahydrofuran (THF), > 99\%, A.C.S. reagent; 4-aminothiophenol, 97\% purity; ethanol, $\geq 99.5 \%$, anhydrous grade. Tetrakis(dimethylamido)titanium, $\geq 99.999 \%$ purity based on metals analyzed, and $\geq 99 \%$ purity based on an assay by NMR, was obtained from Schumacher (Carlsbad,CA). The following chemicals were used as received from Mallinckrodt Baker Inc. (Phillipsburg, NJ): $\mathrm{CMOS}^{\mathrm{TM}}$ grade acetone, and $\mathrm{CMOS}^{\mathrm{TM}}$ grade 2-propanol. Nanostrip from Cyantek Corp. (Fremont, CA) was also used as received.

\section{Synthesis of thiophene ligands.}

General. The schematics of the synthetic procedure are given in Fig. S1. Copper(I) iodide (98\%), CuI, and Tetrakis(triphenylephosphine)palladium(0) (99.9+\%), $\mathrm{Pd}\left(\mathrm{PPh}_{3}\right)_{4}$, were purchased from Strem and used as received. 3-ethynylthiophene, 2 1, 1-Bromo-4trimethylsilylethynylbenzene, $\mathbf{3}^{2}$, and 4-iodo- $N$-isopropylaniline were synthesized using literature procedures. $^{3}$ NMR spectra were obtained using Varian XL-400, INOVA-400 and Unity-500 spectrometers, and chemical shifts are reported relative to benzene- $\mathrm{d}_{6}\left({ }^{1} \mathrm{H}, \delta 7.15\right.$; $\left.{ }^{13} \mathrm{C}\left\{{ }^{1} \mathrm{H}\right\}, \delta 128.00\right)$. Where shifts within a conjugated ring system are reported, the following nomenclature is adapted: The thiophene ring is herein described as ring " $\mathrm{A}$ " and subsequent rings "B," and, where applicable, "C."

Preparation of (4). A $250 \mathrm{~mL} \mathrm{3-neck} \mathrm{round} \mathrm{bottom} \mathrm{flask} \mathrm{was} \mathrm{charged} \mathrm{with} 125 \mathrm{~mL}$ of triethylamine and sparged with argon for $20 \mathrm{~min} .6 .60 \mathrm{~g},(26 \mathrm{mmol})$ of 3 and $3.10 \mathrm{~g}(28 \mathrm{~mol})$ of 2 were added, resulting in a suspension. $\mathrm{Pd}\left(\mathrm{PPh}_{3}\right)_{4}(0.50 \mathrm{~g}, 0.43 \mathrm{mmol})$ and $\mathrm{CuI}(0.20 \mathrm{~g}, 1.1$ 
mmol) were added under argon purge. The flask was equipped with a reflux condenser and the system was refluxed under argon for $12 \mathrm{~h}$. The reaction mixture turned from pale yellow to dark brown and a white solid precipitated. After cooling to $23{ }^{\circ} \mathrm{C}$, saturated aqueous ammonium chloride was added and the aqueous layer assumed a deep blue color while the organic layer remained amber brown. To this mixture was added chloroform and the resulting organic layer was separated and washed three times with $200 \mathrm{~mL}$ of saturated aqueous ammonium chloride. The organic layer was then dried over magnesium sulfate, filtered and concentrated via rotary evaporation to yield a crude yellow solid. The crude solid was taken into warm ethanol and allowed to cool to room temperature and stand for $16 \mathrm{~h}$, after which time $5.90 \mathrm{~g}(81 \%)$ of white crystals were collected. ${ }^{1} \mathrm{H}$ NMR $\left(400 \mathrm{MHz}, \mathrm{C}_{6} \mathrm{D}_{6}\right) \delta 0.22\left(\mathrm{~s}, 9 \mathrm{H}, \mathrm{SiCH}_{3}\right), 6.67(\mathrm{dd}, 1 \mathrm{H}$, $\left.\mathrm{J}=3.2 \mathrm{~Hz}, \mathrm{~J}=5.2 \mathrm{~Hz}, \mathrm{~A}_{4}\right), 7.00\left(\mathrm{dd}, 1 \mathrm{H}, \mathrm{J}=1.2 \mathrm{~Hz}, \mathrm{~J}=5.2 \mathrm{~Hz}, \mathrm{~A}_{5}\right), 7.16(\mathrm{dd}, 1 \mathrm{H}, \mathrm{J}=1.2 \mathrm{~Hz}, \mathrm{~J}=3.2 \mathrm{~Hz}$, $\left.\mathrm{A}_{2}\right), 7.25$ (q, 4H, J=10.8Hz, J=8.8Hz, $\mathrm{B}_{2,3,5,6}{ }^{13} \mathrm{C}\{\mathrm{H}\} \mathrm{NMR}\left(100.5 \mathrm{MHz}, \mathrm{C}_{6} \mathrm{D}_{6}\right) \delta-0.05\left(\mathrm{SiCH}_{3}\right)$, 87.21 (A-CC-B), 89.13 (A-CC-B), 96.37 (B-CC-Si), 105.49 (B-CC-Si), 122.54 (B B $\left._{4}\right), 123.34$ $\left(\mathrm{A}_{2}\right), 123.85\left(\mathrm{~A}_{5}\right), 125.70\left(\mathrm{~B}_{2}\right), 129.14\left(\mathrm{~A}_{3}\right), 129.92\left(\mathrm{~A}_{4}\right), 131.68\left(\mathrm{~B}_{3}\right), 132.22\left(\mathrm{~B}_{1}\right)$.

Preparation of (5). A $250 \mathrm{~mL}$ round bottom flask was charged with $6.00 \mathrm{~g}(21.4 \mathrm{mmol})$ of 4 , $2.40 \mathrm{~g}$ of $\mathrm{KOH}(42.8 \mathrm{mmol}), 200 \mathrm{~mL}$ of methanol and $100 \mathrm{~mL}$ of THF, which resulted in a light amber solution. The solution was stirred at $23{ }^{\circ} \mathrm{C}$ for $24 \mathrm{~h} .400 \mathrm{~mL}$ of distilled water were added and the resulting suspension was extracted three times with $100 \mathrm{~mL}$ portions of chloroform. The combined chloroform extracts were dried with magnesium sulfate and filtered. The resulting filtrate was concentrated via rotary evaporation, resulting in an off-white amorphous solid. The solid was dissolved in boiling benzene and filtered while hot. The filtrate was cooled to room temperature. After $1 \mathrm{~h}$, an off-white precipitate formed, which was collected $(4.99 \mathrm{~g}, 89 \%)$ via vacuum filtration. ${ }^{1} \mathrm{H}$ NMR (400 MHz, $\left.\mathrm{C}_{6} \mathrm{D}_{6}\right) \delta 2.74(\mathrm{~s}, 1 \mathrm{H}, \mathrm{B}-\mathrm{CC} H), 6.65(\mathrm{dd}, 1 \mathrm{H}, \mathrm{J}=3.2$, 
$\left.5.2 \mathrm{~Hz}, \mathrm{~A}_{4}\right), 7.00\left(\mathrm{dd}, 1 \mathrm{H}, \mathrm{J}=4.8 \mathrm{~Hz}, 1.2 \mathrm{~Hz}, \mathrm{~A}_{5}\right), 7.15\left(\mathrm{dd}, 1 \mathrm{H}, \mathrm{J}=2.8,1.2 \mathrm{~Hz}, \mathrm{~A}_{2}\right),(\mathrm{q}, 4 \mathrm{H}, \mathrm{J}=3.6 \mathrm{~Hz}$

8.4Hz, $\left.\mathrm{B}_{2,3,5,6)}\right){ }^{13} \mathrm{C}\{\mathrm{H}\}$ NMR (100.5 MHz, $\left.\mathrm{C}_{6} \mathrm{D}_{6}\right) \delta 79.50$ (B-CCH), 83.42 (A-CC-B), 87.18 (B$\mathrm{CCH}), 88.97(\mathrm{~A}-\mathrm{CC}-\mathrm{B}), 122.36\left(\mathrm{~B}_{1}\right), 122.46\left(\mathrm{~B}_{4}\right), 124.07\left(\mathrm{~A}_{2}\right), 125.70\left(\mathrm{~A}_{5}\right), 129.21\left(\mathrm{~A}_{3}\right), 129.91$ $\left(\mathrm{A}_{4}\right), 131.67\left(\mathrm{~B}_{2}\right), 132.37\left(\mathrm{~B}_{3}\right)$.

Preparation of (6) - 2P SAM ligand. To a $250 \mathrm{~mL}$ round bottom flask was added $1.73 \mathrm{~g} \mathrm{(6.63}$ mmol) of 4-Iodo- $N$-isopropylaniline, $1.56 \mathrm{~g}$ (7.29 mmol), $0.2 \mathrm{~g}(1.1 \mathrm{mmol})$ of copper(I) iodide, $0.5 \mathrm{~g}(0.43 \mathrm{mmol})$ of $\mathrm{Pd}\left(\mathrm{PPh}_{3}\right)_{4}, 50 \mathrm{~mL}$ of toluene and $10 \mathrm{~mL}$ of triethylamine. The resulting mixture was stirred at $23{ }^{\circ} \mathrm{C}$. A white precipitate formed. After $12 \mathrm{~h}, 40 \mathrm{~mL}$ of saturated ammonium chloride and $50 \mathrm{~mL}$ of chloroform were added to the mixture, resulting in a deep blue aqueous layer and a yellow-brown organic layer. The organic layer was separated, washed three times with saturated ammonium chloride, dried over magnesium sulfate, filtered and concentrated via rotary evaporation to yield a crude tan solid. This solid was washed with benzene, and then hexanes, to remove impurities and then dried en vacuo to give $2.00 \mathrm{~g}(88 \%)$ of a light tan powder. ${ }^{1} \mathrm{H}$ NMR $\left(400 \mathrm{MHz}, \mathrm{C}_{6} \mathrm{D}_{6}\right) \delta .77\left(\mathrm{~d}, 6 \mathrm{H}, \mathrm{J}=8.4 \mathrm{~Hz}, \mathrm{NC}\left(\mathrm{CH}_{3}\right)_{2}\right), 3.02(\mathrm{br} \mathrm{s}$, $1 \mathrm{H}, \mathrm{NH}), 3.15\left(\mathrm{sept}, 1 \mathrm{H}, \mathrm{J}=8.4 \mathrm{~Hz}, \mathrm{NCH}\left(\mathrm{CH}_{3}\right)_{2}\right), 6.20\left(\mathrm{~d}, 2 \mathrm{H}, \mathrm{J}=11.2 \mathrm{~Hz}, \mathrm{C}_{2,6}\right), 6.66(\mathrm{dd}, 1 \mathrm{H}, \mathrm{J}=$ $\left.6.8 \mathrm{~Hz}, 4.4 \mathrm{~Hz}, \mathrm{~A}_{4}\right), 7.02\left(\mathrm{~d}, 1 \mathrm{H}, \mathrm{J}=6.8 \mathrm{~Hz}, \mathrm{~A}_{5}\right), 7.37\left(\mathrm{q}, 4 \mathrm{H}, \mathrm{J}=10.8 \mathrm{~Hz}, \mathrm{~B}_{2,3,5,6}\right), 7.55(\mathrm{~d}, 2 \mathrm{H}, \mathrm{J}=$ $\left.11.2 \mathrm{~Hz}, \mathrm{C}_{3,5}\right)$. The resonance for $\mathrm{A}_{2}$ was obscured by the solvent peak. ${ }^{13} \mathrm{C}\{\mathrm{H}\}$ NMR $\left(100.5 \mathrm{MHz}, \mathrm{THF}-\mathrm{d}_{8}\right) \delta 23.08\left(\mathrm{NCH}\left(\mathrm{CH}_{3}\right)_{2}\right), 44.45\left(\mathrm{NCH}\left(\mathrm{CH}_{3}\right)_{2}\right), 87.00$ (A-CC-B), 87.35 (ACC-B), 89.47 (B-CC-C), 94.36 (B-CC-C), $110.23\left(\mathrm{C}_{2}\right), 113.14\left(\mathrm{C}_{4}\right), 123.10\left(\mathrm{~B}_{1}\right), 123.32\left(\mathrm{~B}_{4}\right)$, $125.57\left(\mathrm{~A}_{2}\right), 126.71\left(\mathrm{~A}_{5}\right), 129.87\left(\mathrm{~A}_{3}\right), 130.65\left(\mathrm{~A}_{4}\right), 131.93\left(\mathrm{~B}_{2}\right), 132.23\left(\mathrm{~B}_{3}\right), 133.77\left(\mathrm{C}_{3}\right), 149.70$ $\left(\mathrm{C}_{1}\right)$.

Preparation of (7)-1P SAM ligand. To a 250mL round bottom flask was added $4 \mathrm{~g}$ (15.3 mmol) of 4-Iodo- $N$-isopropylaniline, $1.65 \mathrm{~g}(15.3 \mathrm{mmol})$ of 3-thionylacetylene and $100 \mathrm{~mL}$ of 
triethylamine. The resulting solution was sparged with argon for $30 \mathrm{~min}$ and $0.2 \mathrm{~g}(1.1 \mathrm{mmol})$ of Copper(I) iodide and $0.5 \mathrm{~g}(0.43 \mathrm{mmol})$ of $\mathrm{Pd}\left(\mathrm{PPh}_{3}\right)_{4}$ were added. The reaction was stirred at 23 ${ }^{\circ} \mathrm{C}$ for $12 \mathrm{~h}$ and worked up as 6 . The brown solid was crystalized from ethanol to yield $2.98 \mathrm{~g}$ (81\%) of red-brown crystals, which were collected via vacuum filtration. ${ }^{1} \mathrm{H}$ NMR $(400 \mathrm{MHz}$, $\left.\mathrm{C}_{6} \mathrm{D}_{6}\right) \delta .79\left(\mathrm{~d}, 6 \mathrm{H}, \mathrm{J}=6.4 \mathrm{~Hz} \mathrm{NC}\left(\mathrm{CH}_{3}\right)_{2}\right), 3.06($ br s, $1 \mathrm{H}, \mathrm{NH}), 3.15($ sept, $1 \mathrm{H} \mathrm{J}=6.4 \mathrm{~Hz}$ $\left.\mathrm{NCH}\left(\mathrm{CH}_{3}\right)_{2}\right), 6.20\left(\mathrm{~d}, 2 \mathrm{H}, \mathrm{J}=8.8 \mathrm{~Hz}, \mathrm{~B}_{2,6}\right), 6.70\left(\mathrm{dd}, 1 \mathrm{H}, \mathrm{J}=4.8 \mathrm{~Hz}, 3.2 \mathrm{~Hz}, \mathrm{~A}_{4}\right), 7.10(\mathrm{dd}, 1 \mathrm{H}$, $\left.\mathrm{J}=5.2 \mathrm{~Hz}, 1.2 \mathrm{~Hz}, \mathrm{~A}_{5}\right), 7.21\left(\mathrm{dd}, 1 \mathrm{H}, \mathrm{J}=2.8 \mathrm{~Hz}, 1.2 \mathrm{~Hz}, \mathrm{~A}_{2}\right), 7.50\left(\mathrm{~d}, 2 \mathrm{H}, 8.8 \mathrm{~Hz}, \mathrm{~B}_{3,5}\right),{ }^{13} \mathrm{C}\{\mathrm{H}\} \mathrm{NMR}$ $\left(100.5 \mathrm{MHz}, \mathrm{C}_{6} \mathrm{D}_{6}\right) \delta 22.52\left(\mathrm{NCH}\left(\mathrm{CH}_{3}\right)_{2}\right), 43.63\left(\mathrm{NCH}\left(\mathrm{CH}_{3}\right)_{2}\right), 82.96$ (A-CC-B), 90.91 (A-CCB), $111.19\left(\mathrm{~B}_{4}\right), 112.99\left(\mathrm{~B}_{2}\right), 123.85\left(\mathrm{~A}_{2}\right), 125.32\left(\mathrm{~A}_{5}\right), 127.60\left(\mathrm{~A}_{3}\right), 130.15\left(\mathrm{~A}_{4}\right), 133.29\left(\mathrm{~B}_{3}\right)$, $147.74\left(B_{1}\right)$.

Substrate preparation. The starting substrates were $100 \mathrm{~mm}$ single side polished, $500-550 \mu \mathrm{m}$ thick Si (100) wafers, doped with B to a resistivity of $38-63 \Omega-\mathrm{cm}$. The substrates were scribed with a diamond scribe and subsequently cleaved into 16 samples, each a square of $16.75 \times 16.75$ $\mathrm{mm}^{2}$. After cleaving, the samples were cleaned in Nanostrip solution at $75^{\circ} \mathrm{C}$, to remove the organic contaminants on the surface. These samples were immediately transferred to a CVC SC4500 evaporation system (Cornell Nanoscale Facility). E-beam evaporation was employed to deposit $100 \AA$ of $\mathrm{Cr}\left(\right.$ at $\left.1 \AA-\mathrm{s}^{-1}\right)$ as an adhesion layer followed by $2000 \AA$ of $\mathrm{Au}\left(\right.$ at $\left.2 \AA-\mathrm{s}^{-1}\right)$. Self-assembled monolayers were formed via a liquid phase deposition process. $1 \mathrm{mM}$ solutions, for both the thiophene ligands, were prepared in THF. The typical deposition time employed was 24 hours. After deposition, the substrates were rinsed in THF for 10 minutes to remove any physisorbed species and/or multilayers. For the 4-aminothiophenol $1 \mathrm{mM}$ solutions in anhydrous ethanol were prepared and the deposition time employed was 24 hours. After deposition, the 
substrates were rinsed in anhydrous ethanol for 10 minutes to remove any physisorbed species and/or multilayers.

B. Characterization of self-assembled monolayers.

Three different analytical techniques were employed to characterize the ordering, thickness, and composition of these monolayers.

Contact angle measurements. Measurements, made with a NRL CA Goniometer (Rame-Hart Inc., Mountain Lakes, NJ), were performed with an advancing droplet volume of at least $3 \mu \mathrm{L}$ and a receding droplet volume of about $2 \mu \mathrm{L}$. Contact angles were measured on each side of the droplet and in five different areas on each sample, and the average of these values is reported.

Ellipsometry. A Gaertner L-120A ellipsometer, which employs a He-Ne (632.8 nm) laser light source incident at $70^{\circ}$ with respect to the surface normal, was employed to measure film thickness. A refractive index of $1.45^{4}$ was used to calculate the film thickness, and the index was assumed to be isotropic, which introduces some additional uncertainty (anisotropy is expected for the SAMs). Typically, measurements were made on five different areas of each sample and then averaged. To compare thicknesses measured via ellipsometry, computer models of the molecular structures were made using $\mathrm{ACD} / \mathrm{ChemSketch}{ }^{\mathrm{TM}}$ package from Advanced Chemistry Development Inc. (Toronto, ON, Canada).

X-ray photoelectron spectroscopy (XPS). The spectra were acquired using a VSW twin anode x-ray source (Mg/Al) and a VSW CLASS 100 concentric hemispherical energy analyzer (VSW Worldwide, Cheshire, U.K.). Mg Ka X-rays ( $\mathrm{h} v=1253.6 \mathrm{eV}$ ) were used throughout this study. Survey scans (e.g. 100-1200 eV kinetic energy) were carried out in the fixed retardation ratio 
(FRR) mode, whereas detailed scans (range of $\sim 20 \mathrm{eV}$ over a single feature) were carried out in the fixed analyzer transmission (FAT) mode. The emission current for the source was $20 \mathrm{~mA}$ and the electron voltage was $12 \mathrm{kV}$. The take-off angle for photoelectrons was $38.5^{\circ}$, unless noted otherwise. For background subtraction a method first proposed by Shirley ${ }^{\mathbf{5}}$ was used. Peak areas and peak positions were obtained by fitting the spectra to a product GaussianLorentzian (G-L) function. Specifically, for the Ti(2p) peak, the data was fit to a G-L function where a ratio of $0.45: 1$ was assumed for the relative areas of the $2 p_{1 / 2}$ and $2 p_{3 / 2}$ peaks. ${ }^{6}$

\section{Adsorption kinetics experiments}

Experimental apparatus. Characterization of the SAMs via XPS, and their reactions with $\mathrm{Ti}\left[\mathrm{N}\left(\mathrm{CH}_{3}\right)_{2}\right]_{4}$ were carried out in a custom built ultra-high vacuum (UHV) chamber described in detail elsewhere. ${ }^{7}$ Briefly, a microcapillary array doser (Burle Technologies Inc., Lancaster, PA) made of lead silicate glass, $(0.3 \mathrm{~mm}$ thick, $18 \mathrm{~mm}$ dia. of capillary area, $5 \mu \mathrm{m}$ pore size, $6 \mu \mathrm{m}$ center to center spacing with solid border) was used to deliver a uniform flux of $\operatorname{Ti}\left[\mathrm{N}\left(\mathrm{CH}_{3}\right)_{2}\right]_{4}$ to the surface of the sample, without producing a significant rise in the background partial pressure. Other details of this setup as well as a procedure for determining an absolute flux have been described elsewhere. ${ }^{8}$ In the study conducted here, an absolute flux of $2.798 \times 10^{13}$ molecules$\mathrm{cm}^{-2}-\mathrm{s}^{-1}$ was calculated. The uncertainty in this flux is on the order of $\pm 30 \%$.

Experimental procedures. Polycrystalline Au substrates, prepared as described above, were used as a reference standard for XPS. After analysis of a clean Au substrate using XPS [scanning the Au (4f) peak], a Au substrate with the self-assembled monolayer was transferred into the ultrahigh vacuum chamber via a fast-entry load-lock. The sample was brought to 
temperature $\left(-50^{\circ} \mathrm{C}\right.$ or $\left.30^{\circ} \mathrm{C}\right)$ and a base pressure of $<7 \times 10^{-9}$ Torr was achieved before spectra were obtained to characterize the unreacted SAM, and to quantify its coverage. Subsequently the SAM surface was exposed to $\operatorname{Ti}\left[\mathrm{N}\left(\mathrm{CH}_{3}\right)_{2}\right]_{4}$ using the doser, where exposures ranged from 60 to 600s. After each exposure, the Ti(2p) peak was scanned in order to quantify the adsorption of $\mathrm{Ti}\left[\mathrm{N}\left(\mathrm{CH}_{3}\right)_{2}\right]_{4}$ on the SAM surface. This was repeated until saturation of the adlayer was apparent. After saturation was attained, detailed scans of the $C(1 s), N(1 s)$ and $S(2 p)$ peaks were also acquired. For studies of the adsorption kinetics the take-off angle of the photoelectrons was fixed at $38.5^{\circ}$, and a $5 \mathrm{~mm}$ diameter circular spot on the sample was analyzed. For the experiments involving a variable $\left(0^{\circ}-64^{\circ}\right)$ take-off angle, a $1 \times 10 \mathrm{~mm}^{2}$ rectangular slit was used to maintain maximum field of focus. All experiments involving ARXPS were conducted at $\mathrm{T}_{\mathrm{s}}=$ $30{ }^{\circ} \mathrm{C}$. Angle-resolved XP spectra of the $\mathrm{Au}(4 \mathrm{f}), \mathrm{S}(2 \mathrm{p})$, and $\mathrm{C}(1 \mathrm{~s})$ peaks were also acquired for the unexposed SAMs to probe for the nature of the SAM-substrate chemical interaction. Ti(2p) ARXPS data was acquired after TDMAT exposures, to probe the spatial extent of the reaction. Peak areas were obtained by numerical integration following a Shirley background subtraction. 


\section{References}

1. Sarkar, A.; Kamath, S.P.M; Bhagwat, L.; Babu, K.N.; Rajalakshmi, K.; Talwar, S.S., Indian J. Chem., 1991, 30B, 360-363.

2. Tour, J. M., Molecular Electronics: Commercial Insights, Chemistry, Devices, Architecture and Programming; World Scientific: New Jersey, 2003; p. 370.

3. Borch, R.F.; Hassid, A. I., J. Org. Chem., 1972, 37, 1673-1674.

4. Walczak, M. M.; Chung, C.; Stole, S. M.; Widrig, C. A.; Porter, M. D. J. Am. Chem. Soc. 1991, 113, 2370-2378.

5. Shirley, D. A. Phys. Rev. B 1972, 5, 4709-4714.

6. Lee, H.; Lee, S. M.; Ada, E. T.; Kim, B.; Weiss, M.; Perry, S. S.; Rabalais, J. W. Nuclear Instruments and Methods in Physics Research B 1999, 157, 226-232.

7. Xia, L. -Q.; Jones, M. E.; Maity, N.; Engstrom, J. R. J. Vac. Sci. Technol. A, 1995, 13, 2651-2664.

8. Killampalli, A. S.; Ma, P. F.; Engstrom, J. R. J. Am. Chem. Soc. 2005, 127, 6300-6310. 


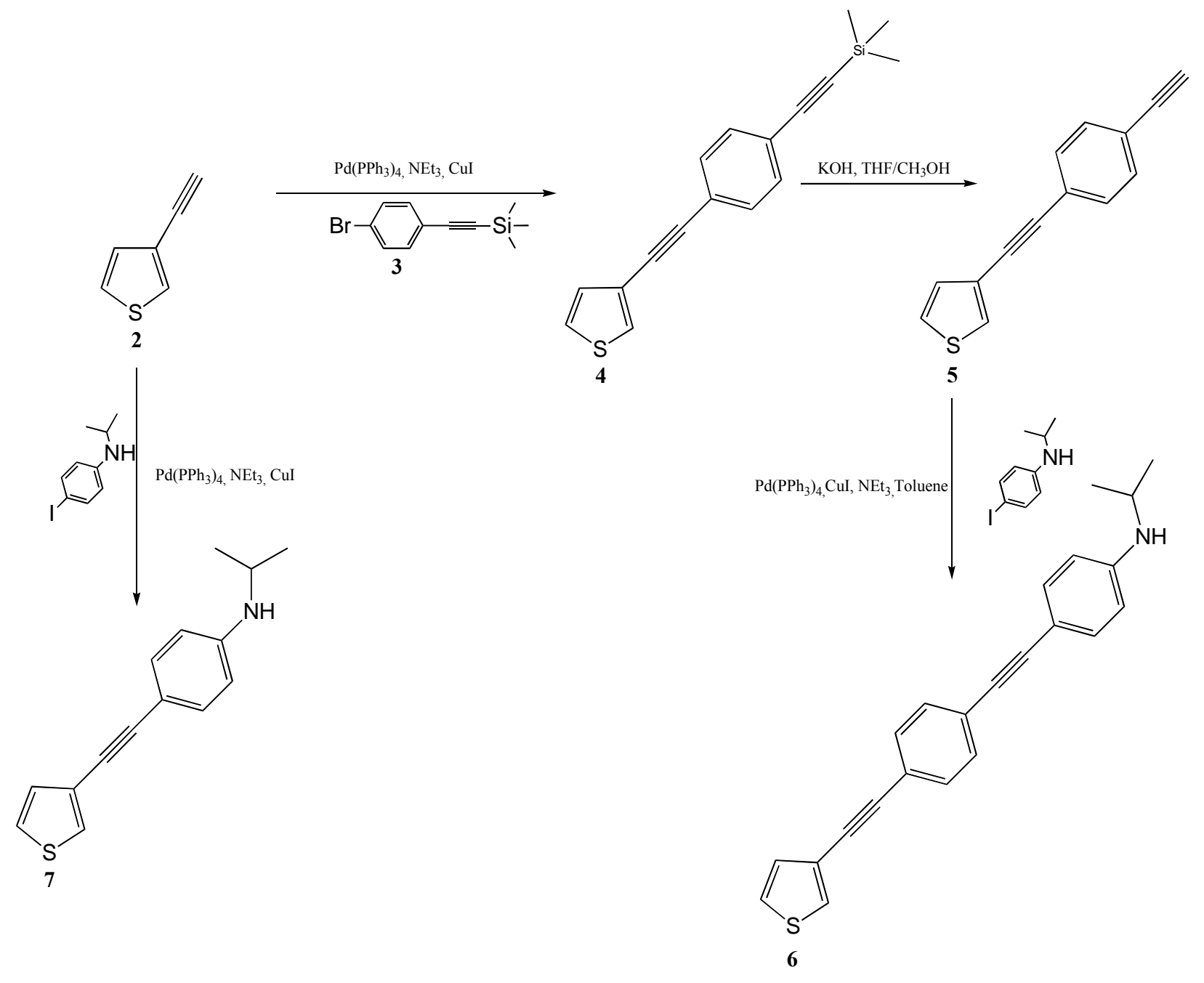

Figure S1. Synthetic scheme 


\section{Table S1}

\section{Parameters from fits to ARXPS data}

\begin{tabular}{|c|c|c|c|c|c|}
\hline SAM & Feature & State & $I\left(\theta_{\mathrm{f}}=0^{\circ}\right)$ & $I_{0}$ & $d / \lambda$ \\
\hline \multirow[t]{7}{*}{$\mathbf{1 P}$} & $\mathrm{Au}(4 \mathrm{f})$ & Clean & $22529 \pm 629$ & $36046 \pm 646$ & $0.47 \pm 0.01$ \\
\hline & $\mathrm{Au}(4 \mathrm{f})$ & $\begin{array}{c}\text { exposed to } \\
\text { Ti }\left[\mathrm{N}\left(\mathrm{CH}_{3}\right)_{2}\right]_{4}\end{array}$ & $27263 \pm 663$ & $43187 \pm 619$ & $0.46 \pm 0.01$ \\
\hline & $S(2 p)$ & Clean & $174 \pm 226$ & $944 \pm 688$ & $1.69 \pm 0.57$ \\
\hline & $S(2 p)$ & $\begin{array}{c}\text { exposed to } \\
\text { Ti }\left[\mathrm{N}\left(\mathrm{CH}_{3}\right)_{2}\right]_{4}\end{array}$ & $171 \pm 308$ & $1023 \pm 1015$ & $1.79 \pm 0.81$ \\
\hline & $C(1 s)$ & Clean & $395 \pm 277$ & $1445 \pm 478$ & $0.32 \pm 0.14$ \\
\hline & $\mathrm{C}(1 \mathrm{~s})$ & $\begin{array}{c}\text { exposed to } \\
\text { Ti }\left[\mathrm{N}\left(\mathrm{CH}_{3}\right)_{2}\right]_{4}\end{array}$ & $390 \pm 54$ & $1137 \pm 71$ & $0.42 \pm 0.04$ \\
\hline & $\operatorname{Ti}(2 p)$ & $\begin{array}{l}\text { exposed to } \\
\text { Ti }\left[\mathrm{N}\left(\mathrm{CH}_{3}\right)_{2}\right]_{4}\end{array}$ & $127 \pm 115$ & $127 \pm 77$ & $0.002 \pm 0.3$ \\
\hline \multirow[t]{7}{*}{$2 P$} & $\mathrm{Au}(4 \mathrm{f})$ & Clean & $19868 \pm 926$ & $32431 \pm 863$ & $0.49 \pm 0.02$ \\
\hline & $\mathrm{Au}(4 \mathrm{f})$ & $\begin{array}{c}\text { exposed to } \\
\mathrm{Ti}\left[\mathrm{N}\left(\mathrm{CH}_{3}\right)_{2}\right]_{4}\end{array}$ & $20949 \pm 1980$ & $32204 \pm 1756$ & $0.43 \pm 0.04$ \\
\hline & $S(2 p)$ & Clean & $179 \pm 259$ & $1391 \pm 1106$ & $2.05 \pm 0.65$ \\
\hline & $S(2 p)$ & $\begin{array}{c}\text { exposed to } \\
\mathrm{Ti}\left[\mathrm{N}\left(\mathrm{CH}_{3}\right)_{2}\right]_{4}\end{array}$ & $94 \pm 125$ & $326 \pm 247$ & $1.24 \pm 0.57$ \\
\hline & $C(1 s)$ & Clean & $577 \pm 125$ & $1169 \pm 110$ & $0.68 \pm 0.12$ \\
\hline & $\mathrm{C}(1 \mathrm{~s})$ & $\begin{array}{c}\text { exposed to } \\
\mathrm{Ti}\left[\mathrm{N}\left(\mathrm{CH}_{3}\right)_{2}\right]_{4}\end{array}$ & $554 \pm 28$ & $887 \pm 18$ & $0.98 \pm 0.05$ \\
\hline & $\operatorname{Ti}(2 p)$ & $\begin{array}{c}\text { exposed to } \\
\mathrm{Ti}\left[\mathrm{N}\left(\mathrm{CH}_{3}\right)_{2}\right]_{4}\end{array}$ & $101 \pm 58$ & $101 \pm 38$ & $0.0 \pm 0.2$ \\
\hline \multirow[t]{7}{*}{ 4-aminothiophenol } & $\mathrm{Au}(4 \mathrm{f})$ & Clean & $19380 \pm 1072$ & $31634 \pm 1117$ & $0.49 \pm 0.02$ \\
\hline & $\mathrm{Au}(4 \mathrm{f})$ & $\begin{array}{c}\text { exposed to } \\
\mathrm{Ti}\left[\mathrm{N}\left(\mathrm{CH}_{3}\right)_{2}\right]_{4}\end{array}$ & $23563 \pm 643$ & $36955 \pm 639$ & $0.45 \pm 0.01$ \\
\hline & $S(2 p)$ & Clean & $290 \pm 88$ & $1063 \pm 185$ & $1.30 \pm 0.13$ \\
\hline & $S(2 p)$ & $\begin{array}{c}\text { exposed to } \\
\mathrm{Ti}\left[\mathrm{N}\left(\mathrm{CH}_{3}\right)_{2}\right]_{4}\end{array}$ & $288 \pm 230$ & $1454 \pm 652$ & $1.62 \pm 0.35$ \\
\hline & $\mathrm{C}(1 \mathrm{~s})$ & Clean & $628 \pm 84$ & $1038 \pm 57$ & $0.93 \pm 0.12$ \\
\hline & $\mathrm{C}(1 \mathrm{~s})$ & $\begin{array}{c}\text { exposed to } \\
\mathrm{Ti}\left[\mathrm{N}\left(\mathrm{CH}_{3}\right)_{2}\right]_{4}\end{array}$ & $718 \pm 337$ & $1948 \pm 413$ & $0.46 \pm 0.15$ \\
\hline & $\operatorname{Ti}(2 p)$ & $\begin{array}{c}\text { exposed to } \\
\text { Ti[ }\left[\mathrm{N}\left(\mathrm{CH}_{3}\right)_{2}\right]_{4}\end{array}$ & $84 \pm 24$ & $94 \pm 17$ & $0.11 \pm 0.10$ \\
\hline
\end{tabular}

